\title{
MACHADO DE ASSIS' HOMEOPATHIC NARRATORS
}

\section{PAUL DIXON}

Purdue University

West Lafayette, Indiana, EUA

\begin{abstract}
Machado showed a fascination with homeopathic medicine, an indirect form of treatment that uses agents to stimulate reactions similar to the symptoms of the condition to be cured. Several of the author's texts show a pattern of projects realized by indirect means, by "like curing like", which suggests a homeopathic logic in Machado's worldview. Certain narrators, such as those in Memórias póstumas de Brás Cubas, Dom Casmurro, and in short stories such as "O segredo do bonzo" and "Adão e Eva", are notable for denouncing themselves, that is, for undermining their own validity. This curious situation has implications for Machado's overall project, which seems more interested in posing questions than providing answers. It also suggests a particular relationship with the reader, which affords as much independence as possible.
\end{abstract}

Keywords: Machado de Assis; narrator; homeopathy; reader.

\section{OS NARRADORES HOMEOPÁTICOS DE MACHADO DE ASSIS}

Resumo: Machado demonstrou fascínio pela medicina homeopática, uma forma indireta de tratamento que usa substâncias para estimular reações semelhantes aos sintomas da condição a ser curada. Vários textos do autor apresentam um padrão em que os projetos são realizados por meios indiretos, pelo "semelhante que cura o semelhante", o que sugere uma lógica homeopática na visão do mundo machadiano. Alguns narradores, tais como os de Memórias póstumas de Brás Cubas, Dom Casmurro, e de contos como "O segredo do bonzo" e "Adão e Eva", são notáveis por se denunciarem a si mesmos, ou seja, por atacarem sua própria validez. Essa situação curiosa contribui para uma noção do projeto geral de Machado, que parece ter mais interesse em colocar perguntas do que em fornecer respostas. Também sugere uma certa relação com o leitor, que lhe dá um máximo de independência.

Palavras-chave: Machado de Assis; narrador; homeopatia; leitor.

D.O.I: $10.1590 / 1983-682120158159$

Este texto está licenciado sob uma Licença Creative Commons do tipo atribuição BY.

Machado de Assis Linha, São Paulo, v. 8, n. 15, p. 134-159, junho 2015

Universidade de São Paulo - Faculdade de Filosofia, Letras e Ciências Humanas 
or many years scholars have recognized that an interesting problematic is at work in the later novels and short stories of the Brazilian writer L Machado de Assis (1839-1908), whereby a great deal of agency is given to the reader. ${ }^{1}$ It could be said that the production of meaning in these works belongs to the reader, with the guidance of certain suggestions from the texts, far more than being simply inherent in the works themselves.

In spite of a general agreement on this, critics are still searching for an adequate theoretical model to explain the dynamics of this reading. On the traditional end of the spectrum, writers talk of Machado's unreliable narrators and the ironic readings they suggest. ${ }^{2}$ There are problems with this paradigm, however, since Machado's narrators are so self-conscious and self-referential. Can we really talk about an unreliable narrator if the clues for reading at odds with the narrator come from that speaker himself? On the more radical end of the spectrum, it has been suggested that post-structuralism may serve as a model for characterizing the Machadian play of disparate meanings. ${ }^{3}$ But when Machado's texts seem to mine and explode their own semantic fissures and crevices, to create indeterminacies through special referential mechanisms within the old "metaphysics of presence", and to distinguish themselves from other less problematic forms of expression, what is gained by bringing up a general theory where all written language is by definition indeterminate?

I will try to suggest a partial solution to this problem of an adequate conceptual model by following a paradigmatic thread through a few of Machado's fictional texts. That thread begins with consideration of one of the author's thematic curiosities.

Although homeopathic medicine could not be called one of Machado de Assis' most insistent topics, the Brazilian author had an undeniable fascination

\footnotetext{
${ }^{1}$ See BORBA, Considerações sobre a recepção de Machado de Assis; CALDWELL, The Brazilian Othello of Machado de Assis; SANTIAGO, Retórica da verossimilhança; and TOSTA, Machado de Assis: a obra entreaberta.

${ }^{2}$ KINNEAR, Machado de Assis: To Believe or Not to Believe; CYPESS, Machado de Assis vs. Brás Cubas; COUTINHO, Estudo introdutório; NUNES, The Craft of na Absolute Winner, p. 72-73; FACIOLI, Um defunto estrambótico, p. 63.

${ }^{3}$ DANIEL, Machado de Assis, p. 238-46; FITZ, Machado de Assis, p. 56.
}

Machado de Assis Linha, São Paulo, v. 8, n. 15, p. 134-149, junho 2015

Universidade de São Paulo - Faculdade de Filosofia, Letras e Ciências Humanas 
for the practice. In the novel Dom Casmurro, the "agregado" José Dias is characterized as a devout believer and unlicensed practitioner of homeopathy. A short story entitled "O imortal" has a narrator who is a homeopathic doctor, and a dénouement that hinges on its concepts.

Homeopathy is based on the idea that diseases can be cured with small doses of agents that produce symptoms similar to the disease itself. Similia similibus curantur. Likes cure likes. It is an anti-linear, indirect approach to the curing process, by which the treatment, instead of launching a frontal attack on the ailment, tries to stimulate and reinforce the body's own defensive systems against the disease.

The opposite approach, which has proved to be more popular, is allopathic medicine, whose treatments are intended directly to counteract the physical manifestations of the disease. Contraria contrariis curantur. Opposites cure opposites.

In an essay entitled "A lei da homeopatia", I show that Machado's occasional reference to homeopathic medicine can be taken as an emblem for a general pattern, belonging to a phenomenology of the Brazilian author.4 Focusing on the short story, "Cantiga de esponsais", he claims that this and other texts highlighting the creative process display a sort of homeopathic logic. The person who desires to create something of value, in Machado, will only encounter frustration by employing a direct, concentrated effort. Those familiar with the short story will immediately identify Mestre Romão as the representative of this frontal approach. In the story, as well as in other texts, the winners of the creative prize are the ones who behave as if they don't really care, or as if they intend something other than serious creative production. In "Cantiga", it is the newlywed woman next door, the lover who in her absorption with her new spouse and her aimless vocalizing (her "cantarolar à toa"), finds the musical phrase the erstwhile composer vainly sought for most of his life.

My study suggests that the homeopathic pattern goes beyond the thematics of creativity, and in fact comes to suggest a kind of general Machadian consciousness of the world of human intentions, projects and programs. Machado's esthetic appears to favor a model of accomplishment by indirect means, instead of by straightforwardness. An early story, entitled "Linha reta e linha curva", illustrates the pattern in the domain of courtship. When a suitor

${ }^{4}$ Dixon, A lei da homeopatia, p. 44-50.

Machado de Assis Linha, São Paulo, v. 8, n. 15, p. 134-149, junho 2015

Universidade de São Paulo - Faculdade de Filosofia, Letras e Ciências Humanas 
tries to win the hand of a young lady by showing her in unequivocal terms how interested he is in her, he fails to gain even a moment's attention. A few years later, when the same suitor behaves as if he were completely indifferent to the same young woman, he causes her to fall for him in a serious way. Machado's ways are those of the "linha curva".

In fact, this configuration of the intending subject's project tends toward circularity. The homeopathic treatment, applied in a direction that would seem to reinforce the sickness as manifest, comes full circle to debilitate it from the opposite direction. In one story, the new bride's haphazard humming, intended for pure diversion, comes around to the lost chord. In another, a movement, supposedly towards rejection of the beloved, undertakes a gradual diametric reversal until in the end it transforms itself into reciprocated love.

My purpose is to examine how a similar sort of homeopathic principle tends to operate with some of Machado de Assis' narrators. The short story "Adão e Eva", published first in Gazeta de Notícias in 1885 and in Várias histórias ten years later, quite clearly illustrates this matter. As with so many stories, "Adão e Eva" is a frame narrative, containing an exterior (or extra-diegetic) narration, and an interior (or diegetic) one. The first involves an evening of food and conversation at the estate of a female plantation owner in Bahia. When a guest wants to know more about one of the sweets being served, the topic of the conversation turns to curiosity. Are men more curious than women, or is it the other way around? And in the case of the first human family - Adam and Eve who was to blame for the expulsion from paradise? Everyone offers an opinion, except for a certain magistrate (juiz de fora). Interrogated by the others, he affirms that the question makes no sense, because things did not happen in the Garden of Eden the way the sacred record indicates. The man then tells his version of the story to the curious guests. At the end of his narration, they all sit stupefied and perplexed, without knowing how to respond. Then the narrator undoes everything by saying, "nada disso aconteceu"5 and asking again about the dessert.

The internal narration, then, is a version of the story of Genesis. It has all the same elements as the Biblical version - the paradisiacal garden, the tree of forbidden fruit, and the serpent (representing Satan) who promises that eating the fruit will bring a great future. To Eve, the serpent prophesies:

${ }^{5}$ ASSIS, Obra completa, v. 2, p. 528.

Machado de Assis Linha, São Paulo, v. 8, n. 15, p. 134-149, junho 2015

Universidade de São Paulo - Faculdade de Filosofia, Letras e Ciências Humanas 
[...] serás legião, fundarás cidades, e chamar-te-ás Cleópatra, Dido, Semíramis; darás heróis do teu ventre, e serás Cornélia; ouvirás a voz do céu e serás Débora; cantarás e serás Safo. E um dia, se Deus quiser descer à terra, escolherá as tuas entranhas, e chamar-te-ás Maria de Nazaré. ${ }^{6}$

So far, we have the well-known story. In the magistrate's version, however, both Eve and Adam obey the divine prohibition. Neither one yields to the temptation to taste the fruit of the tree of the knowledge of good and evil. And to reward them for their obedience, God delivers all the earth to the devil and instructs the angel Gabriel to take them away:

[...] então Gabriel deu as mãos a ambos, e os três subiram até a estância eterna, onde miríades de anjos os esperavam, cantando:

- Entrai, entrai. A terra que deixastes, fica entregue às obras do Tinhoso, aos animais ferozes e maléficos, às plantas daninhas e peçonhentas, ao ar impuro, à vida dos pântanos. Reinará nela a serpente que rasteja, babuja e morde, nenhuma criatura igual a vós porá entre tanta abominação a nota da esperança e da piedade. ${ }^{7}$

The magistrate's ending is disconcerting to his audience because it is contradicted by the obvious fact of their very existence. In Genesis, the expulsion of Adam and Eve from the garden places them in the real world and renders them mortal, which means that they can begin producing offspring. The assumption of everyone present is that they are descendants of Adam and Eve. How can the first couple have been transported directly to heaven, if their descendants attest to their having remained on earth? Small wonder, then, that the guests "olhavam uns para os outros, embasbacados; em vez de explicação, ouviam uma narração enigmática, ou, pelo menos, sem sentido aparente". 8

D. Leonor, the hostess, suggests that the magistrate "estava logrando a gente", 9 which causes him to admit:

- Pensando bem, creio que nada disso aconteceu; mas também, d. Leonor,

${ }^{6} I d e m$, v. 2, p. 527.

${ }^{7}$ Idem, v. 2, p. 528.

${ }^{8}$ Ibidem.

${ }^{9}$ Ibidem.

Machado de Assis Linha, São Paulo, v. 8, n. 15, p. 134-149, junho 2015

Universidade de São Paulo - Faculdade de Filosofia, Letras e Ciências Humanas 
se tivesse acontecido, não estaríamos aqui saboreando este doce, que está, na verdade, uma cousa primorosa. É ainda aquela sua antiga doceira de Itapagipe? ${ }^{10}$

The magistrate, then, has been a very homeopathic narrator, for in "taking back" the story he has told, in readily admitting its lack of validity, he has caused his interesting version of the account to float in a kind of epistemological weightlessness. Like a medicine in which like cures like, he has taken his own self out of play as a provider of knowledge. The reader must now grapple with an ungrounded narrative, devoid of any sort of serious projections, perhaps asking, "So why even tell the story? If it is patently invalid, what can its importance be?".

That sense of a message is left completely in the hands of the reader. For my part, I see the story as a critique of the traditional, negative view of the fall of Adam and Eve (and we should acknowledge that the accusation has traditionally been directed at the woman). The conversation about them suggests this negativity by asking "who was to blame". And yes, one or both of them does apparently have responsibility, according to the Bible, for introducing humanity to this trying state, this "vale of tears". However, the magistrate, who insists on how delicious the sweets are, seems to be suggesting that if Adam and Eve get the blame for casting us into a lone and dreary world, they should also get some credit for the wonderful desserts we are sometimes allowed to enjoy.

A short story in the 1882 volume Papéis avulsos, published previously in the Gazeta de Notícias and entitled "O segredo do bonzo", illustrates a very similar problematic. The subtitle tells us that the text is a "Capítulo inédito de Fernão Mendes Pinto". ${ }^{11}$ The narrator, then, is none other than the famous chronicler of the Portuguese discoveries, who promises to reveal a curious and edifying doctrine which he has encountered in his travels to the city of Fuchéu, kingdom of Bungo. Pinto and his interpreter, the physician Diogo Meireles, and a native sandal maker, Titané, discover large, applauding crowds gathered around men pronouncing outrageous messages. One has discovered the origin of crickets in the conjunction of air, coconut leaves and the new moon; the other

${ }^{10}$ Ibidem.

${ }^{11}$ Idem, v. 2, p. 323. 
has found the key to the future destruction of the world in a drop of cow's blood. Their enthusiastic listeners regale them with gifts and sumptuous food.

They learn that these orators are in all likelihood disciples of the great bonze Pomada, and resolve to simulate discipleship, in order to learn the bonze's secret doctrine. Later, at the feet of the master, this is the lesson they learn:

[...] se uma cousa pode existir na opinião, sem existir na realidade, e existir na realidade, sem existir na opinião, a conclusão é que das duas existências paralelas a única necessária é a da opinião, não a da realidade, que é apenas conveniente. ${ }^{12}$

Pomada then urges them to put the doctrine to the test, inventing their own implausible orations and trying them out on the public. Indeed, each of the three fabricates a profitable falsehood, and succeeds in convincing the public of its veracity. We assume that these falsehoods are distinguished as such, or bracketed off from the rest of the text.

First, the sandal maker, whose product is in fact mediocre at best, invents reports that people from Malabar, China and other remote parts are clamoring to buy his most excellent and famous sandals, that a dozen mandarins have insisted they be given the honorific title of "state sandal", and that he has had to wear himself out to produce enough footwear to satisfy the demand, not to mention enough to give numerous pairs away to the poor of the city. He insists that he does all this not for personal profit, but for the glory of the kingdom of Bungo. In no time, sales of the sandals rise to astronomical levels.

The narrator, in turn, decides to claim that he is the world's greatest virtuoso of the native oboe, an instrument he barely plays. By engaging in exaggeratedly expressive choreography as he plays, after having the instrument brought to him on a splendid silver tray, he obtains wildly enthusiastic applause from his audience. He also is careful to point out that the honor he aims at is not personal, but rather, for the kingdom of Bungo.

The greatest rhetorical feat belongs to the interpreter and doctor, Diogo Meireles. A terrible disease has been growing in the city, whose primary symptom is the swelling of the nose until it occupies more than half of the face.

${ }^{12}$ Idem, v. 2, p. 325. 
The only effective cure so far discovered has been amputation. Understandably, patients have been reluctant to submit to such a treatment. Claiming that it is strictly for the benefit of the kingdom of Bungo, Meireles therefore invents the discovery of a metaphysical nose, which is entirely inaccessible to the senses, but which can nevertheless effectively occupy the place of the former, diseased nose. The doctor describes this discovery in such lofty tones that all the previously hesitant patients now eagerly agree to be "desnarigados". The ultimate proof of the doctor's rhetorical success is that "todos os desnarigados de Diogo Meireles continuaram a prover-se dos mesmos lenços de assoar". ${ }^{13}$

On the surface, the text appears to be a delightful "tall tale", a satirical treatment of the amorality of self-interested rhetoric and the gullibility of audiences. The narrator seems to establish a degree of reliability with the reader by openly admitting to the deceptive status of the oratorical experiments. The reader naturally delights at being let in on the joke, acting as a sort of coconspirator with the narrator. Once this reliability of the narrator as plotting partner is established, however, the text effects a decidedly homeopathic turnabout, which, I think, completely changes the previous alliance between the narrator and the reader. Immediately after the remark about real handkerchiefs to blow metaphysical noses, the narrator concludes by employing the rhetorical commonplace of unselfish motivation, saying, "O que tudo deixo relatado para glória do bonzo e benefício do mundo". ${ }^{14}$

The previous examples of unauthentic oratory, dealing with sandals, oboe virtuosity and metaphysical noses, were all presented as experimental demonstrations of the efficacy of the bonze's doctrine. As part of this rhetoric, all three speakers have made a big point of affirming that their goal is not personal gain, but the glory of the kingdom of Bungo. The reader, eager to assume the conspiratorial role, has probably assumed that the demonstration of convincing but false discourse is limited to those episodes. However, the concluding sentence, "All of which I tell for the glory of the bonze and the benefit of the world", shows that the true confines of the experiment in false but convincing discourse are wider than that. The account as a whole is now seen to belong to the same category of speech. The entire text qualifies as a rhetorical exercise, and as a demonstration of the efficacy of the bonze Pomada's doctrine.

${ }^{13}$ Idem, v. 2, p. 328.

${ }^{14}$ Ibidem.

Machado de Assis Linha, São Paulo, v. 8, n. 15, p. 134-149, junho 2015

Universidade de São Paulo - Faculdade de Filosofia, Letras e Ciências Humanas 
The narrator has, in effect, amputated his own nose of reliability. The frankness, with which the narrator has told of his deception of previous audiences, now extends beyond the confines of those incidents. That same frankness now tells us that we have also been part of the same rhetorical situation. Readers who previously identified with the deceptive orators must now adjust to identifying with the duped audiences.

Of course, we should have seen it coming. Readers familiar with Fernão Mendes Pinto, who according to the story's subtitle is the author of the text, should have been wary, for nearly everyone acknowledges that at least part of the content of his travelogues must belong to the category of fiction rather than history. We might even recall that malicious nickname, "Fernão, mentes? Minto". But, as Wayne Booth has shown, there is such a strong conventional authority given to narrators, that readers tend to assume reliability unless substantial evidence indicates otherwise. ${ }^{15}$ Booth says that a sense of unreliability arises when we perceive a lack of compatibility between what the narrator tells us and "the norms of the work" ${ }^{16}$ In practice, these norms would seem to be established by actions represented, in other words, what the narration shows us. However, what is curious about Machado's narrator in "O segredo do bonzo" is that the disjunction arises between what the narrator tells us at point A, and what the narrator tells us at point B. First, the narrator says he is merely "playing along" with the bonze, in order to satisfy his curiosity. Later, however, he tells us that the whole story is offered for the glory of the bonze, and the benefit of the world. A concealed conversion has taken place, which causes the narrator's candid telling to end up telling on itself. We have here something other than an unreliable narrator, in Booth's conception, because in order eventually to distance ourselves from the narrator, we continue to depend on the reliability of what he tells us. I believe that this narrative configuration where like counteracts like, this dog that bites his own tail, is an important pattern that extends far beyond the bounds of Machado's curious short story.

I turn now to Memórias póstumas de Brás Cubas for another take on the narrative pattern. It has been widely claimed that Machado's fifth novel presents a clear exposition of a pessimistic worldview. That account would seem to start with the introductory note to the reader, where Brás Cubas refers

${ }^{15}$ BOOTH, The Rhetoric of Fiction, p. 3-4.

${ }^{16}$ Idem, p. 158.

Machado de Assis Linha, São Paulo, v. 8, n. 15, p. 134-149, junho 2015

Universidade de São Paulo - Faculdade de Filosofia, Letras e Ciências Humanas 
to his "rabugens de pessimismo", ${ }^{17}$ later to include, in the famous Delirium chapter, a powerful vision of human suffering, anguish and futility throughout the centuries, and to reach its conclusion in the last chapter, where the author reviews the failures of his life but finds a "pequeno saldo"18 in the fact that he had no children, and thus did not transmit to anyone "o legado da nossa miséria". ${ }^{19}$ Many have made the highly problematic move of attributing such a view to Machado himself, in spite of the fact that at no point, not even in the author's prolog to the third edition, ${ }^{20}$ does he speak for himself. But even to assume that the fictional narrator is unproblematically pessimistic is, in my view, a reductive view of a knotty problem.

The chapter entitled "O delírio", in which before his death, Brás Cubas has a vision of the origin of time and the ceaseless vain march of humanity, is considered to be a centerpiece of the novel's purported "philosophy" or "worldview". Such a position, however, is hard to justify in view of the narrative context in which the delirium is represented. Abel Barros Baptista states the problem effectively:

[C]omo entender que um delírio, ademais delírio de moribundo, um momento de sandice, como o próprio Brás Cubas depois o qualifica, possa valer como explicitação da filosofia de Machado de Assis? [... E mesmo se] quem fala é o "genuíno Machado" e não apenas Brás Cubas, por que razão se há-de pensar que fala para explicitar uma filosofia e não para relativizar ou parodiar uma filosofia que não partilha? ${ }^{21}$

Baptista is critiquing the fallacious tendencies of Machado's readers. I would merely point out that Brás Cubas, as the narrator, buys into the same fallacy. He offers the delirium as exhibit A in his pessimistic indictment of life as "miséria". Yet with characteristic frankness, he also tells us that the delirium belongs to the category of "sandice" or madness. One moment of straightforward information counteracts the other. In effect, the narrator disqualifies himself, by reason of insanity.

\footnotetext{
${ }^{17}$ ASSIS, cit., v. 1, p. 514.

${ }^{18}$ Idem, v. 1, p. 639.

${ }^{19}$ Ibidem.

${ }^{20}$ Idem, v. 1, p. 512.

${ }^{21}$ BAPTISTA, Em nome do apelo do nome, p. 123-124.
} 
A second locus of homeopathic narration in the novel has to do with the question of the author having or not having a name. Memórias póstumas is, of course, a novel disguised as an autobiography, and Brás Cubas is represented as an autobiographer. As Phillippe Lejeune has demonstrated, the specificity of autobiography as a genre in its own right, not to be conflated with other genres such as biography or the autobiographical novel, resides in the coinciding identity of the protagonist of the narration and the name of the author as a real person, responsible for the enunciation. ${ }^{22}$ It is the proper name of the author that gives autobiography its ontological grounding. Lejeune continues,

Perhaps one is an author only with his second book, when the proper name inscribed on the cover becomes the "common factor" of at least two different texts and thus gives the idea of a person who cannot be reduced to any of his texts in particular, and who, capable of producing others, surpasses them all. This we will see, is very important for the reading of autobiographies: if the autobiography is a first book, its author is thus unknown, even if he relates his own story in the book. He lacks, in the eyes of the reader, that sign of reality which is the previous production of other texts (non autobiographical), indispensable to that which we will call "the autobiographical space". ${ }^{23}$

I feel that it may be appropriate to allow for a little more room within that "autobiographical space" than Lejeune specifies. We can understand the word "author" in its etymological sense to include notions such as "creator", "maker" or "doer" and admit the possibility of an autobiographical author who has established a "name" by means other than writing. But otherwise, I would say that Lejeune is right, without the proper name of the author, a name with some weight of accomplishment, which may be commonly known to us outside the domain of the autobiography itself, without that name serving as an anchor to reality, the text has a certain ungrounded-ness.

And that lack of a name, interestingly, is what Memórias póstumas is all about. We note that the narration begins with the account of the narrator's failing to make a name for himself. Brás Cubas clearly states that the motive behind his proposed, but never realized remedy, the "Emplasto" was to see his

${ }^{22}$ LEJEUNE, On Autobiography, p. 11.

${ }^{23}$ Idem, p. 11-12. 
own name known far and wide. ${ }^{24}$ Thereafter, we may read the other events of his life as similar attempts to establish his name. His accounting in the last chapter amounts to a list of lost opportunities to ensure his proper name:"Não alcancei a celebridade do emplasto, não fui ministro, não fui califa, não conheci o casamento [...] não tive filhos [...]". 25

Machado's novel is thus a fictional autobiography, written by an author with no authority. The expected autobiographer's trajectory is first, to establish a name through writing or some other recognized accomplishment, then to write the autobiography, then to die, leaving behind both the autobiography and the other creations as a legacy. This is the trajectory of the "autor defunto" mentioned in the first chapter. ${ }^{26}$ As the narrator is quick to tell us, his text inverts that trajectory. First, the autobiographer fails to establish his name, either through writing or through any other means, then he culminates his inactivity by dying, and then he writes the autobiography. The notion of the "defunto autor", ${ }^{27}$ which etymologically suggests the idea of someone who first is dysfunctional or non-functioning, and then writes about it, brings to mind a special category of autobiographical genre - that of the self-serving autobiography. Currently, I think, it is often referred to as "spin control". Within this mode, authors retrospectively justify their dubious actions or failures, by putting them in the "proper perspective".

As a fictive autobiography, Memórias póstumas belongs to this ungrounded, solipsistic subcategory of the genre, wherein the author has no securely established name outside the domain of the text, but attempts to create the "proper" name within the text itself. Brás Cubas finds the proper context for his ineffectual existence by postulating that human existence is a vain exercise anyway, and that any attempt to create a legacy within that existence would merely be a prolongation of human misery. It is a highly suspect argument, belonging to an ungrounded discursive structure. What is curious, though, is that readers who adopt that distant, critical perspective of the text do so not through some capacity for independent reading between the lines, but rather because the narrator himself gives them the evidence and the logical justification for reading that way.

${ }^{24}$ ASSIS, cit., v. 1, p. 515.

${ }^{25}$ Idem, v. 1, p. 639.

${ }^{26}$ Idem, v. 1, p. 513.

${ }^{27}$ Ibidem.

Machado de Assis Linha, São Paulo, v. 8, n. 15, p. 134-149, junho 2015

Universidade de São Paulo - Faculdade de Filosofia, Letras e Ciências Humanas 
And now to consider, however briefly, the masterpiece Dom Casmurro. The question of the female protagonist's guilt or innocence of adultery is, of course, a crucial issue in the reading of the novel. Critics have claimed that the ambiguity surrounding Capitu's fidelity to her husband derives from the unreliability of that husband, Bento Santiago, as narrator of the account. ${ }^{28}$ But we oversimplify if we state the problem in those terms. For one thing, the facts of the matter are, in themselves, ambiguous. I will give just a couple of examples, although there are many: On the one hand, even Capitu acknowledges that her son, Ezequiel, resembles Escobar, her supposed partner in infidelity and the supposed father of the child. But on the other, the boy's penchant for imitating the gestures and mannerisms of others makes us wonder if a perception of physical resemblance might be based on such mannerisms more than on any genetically-determined similarity. Reinforcing the notion of resemblance based on non-genetic factors is the "unexplainable similarity" discovered between Capitu and the photograph and her friend Sancha's mother.

The evidence of Capitu's character is likewise equivocal. The young woman of the famous hair-combing episode shows herself to be an expert dissimulator and a manipulator of her circumstances. But at other times Capitu blushes or goes pale, cries and explodes with anger or frustration. When we examine the facts that might point to an actual encounter between Capitu and Escobar, we are also left with doubly directed evidence. Escobar may have been found at Capitu's door because he had been there for a tryst. But his own declaration that he had come to discuss a matter of business with Bentinho provides an innocent motive for his presence.

The facts themselves point in both directions. And who has carefully outlined these equivocal facts, but Dom Casmurro, the narrator himself? The traditional critical vocabulary, by which narrators are referred to as reliable or unreliable, is inadequate to describe a narrator who makes claims about his wife's infidelity, but meticulously provides us with details that support an opposing version of the story.

The self-consciousness of the narrator and self-referential character of his discourse also work against any reductive sense of confidence in the narrator. I regard as crucial indeed the digressive chapter in which the narrator discusses his preferred manner of reading. He confesses that he likes reading

${ }^{28}$ COUTINHO, cit.; KINNEAR, cit., p. 54-65.

Machado de Assis Linha, São Paulo, v. 8, n. 15, p. 134-149, junho 2015

Universidade de São Paulo - Faculdade de Filosofia, Letras e Ciências Humanas 
vague books, or books with gaps of information, because he is then able to imagine his own version of the details that have been absent from the text. And he concludes by saying to the reader, "Assim preencho as lacunas alheias; assim podes também preencher as minhas". ${ }^{29}$ This kind of statement wreaks havoc with the idea of a narrator's reliability or lack of reliability. Who advises us to look for crucial gaps in the narration, and to supply our own, independent version of the facts? The very narrator, who has given us those textual facts in the first place. As readers, we are placed in a double bind, because we cannot read contrary to the narrator without, in another way, following the explicit directions of that narrator. We again encounter a situation that may be configured as homeopathy. Like counteracts like; narrative straightforwardness takes a self-devouring turn.

I have tried to show in this discussion that Machado's works show certain patterns, portable patterns, if you will, that have sufficient structural generality to be located at different levels of signification. What appears on the thematic level as a fascination for homeopathic medicine, tends to transfer to a narratological level as a situation where narrators undermine the validity of their own narrations. Perhaps the homeopathic principle can even be taken further, relating to a general consciousness of the world as a self-consuming mechanism, much like the being described in the poem entitled "Uma criatura", ${ }^{30}$ which "a si mesma devora os membros e as entranhas". All of this contributes to a general sense of Machado's literary project as being more involved in the production of questions than in the provision of answers. When it comes to the question of reception, it reveals a bold renunciation of the narrator's authority, and moves to place meaning in the hands of the reader.

\section{References}

ASSIS, Machado de. Obra completa. Rio de Janeiro: Nova Aguilar, 1985, 3 vols.

BAPTISTA, Abel Barros. Em nome do apelo do nome: duas interrogações sobre Machado de Assis. Lisboa: Litoral, 1991.

BOOTH, Wayne C. The Rhetoric of Fiction. 2nd ed. Chicago: University of Chicago Press, 1983.

${ }^{29}$ ASSIS, cit., v. 1, p. 871.

${ }^{30}$ Idem, v. 3, p. 151-152.

Machado de Assis Linha, São Paulo, v. 8, n. 15, p. 134-149, junho 2015

Universidade de São Paulo - Faculdade de Filosofia, Letras e Ciências Humanas 
BORBA, Maria Antonieta Jordão de Oliveira. Considerações sobre a recepção de Machado de Assis. Matraga 15.Rio de Janeiro, UERJ, n. 23, p. 107-121, 2008.

CALDWELL, Helen. The Brazilian Othello of Machado de Assis: A Study of Dom Casmurro. Berkeley: University of California Press, 1960.

COUTINHO, Afrânio. Estudo introdutório. In:ASSIS, Machado de. Dom Casmurro. Rio de Janeiro: Edições de Ouro, n. d.

CYPESS, Sandra Messinger. Machado de Assis vs. Brás Cubas: The Narrative Situation of Memórias póstumas de Brás Cubas. Kentucky Romance Quarterly 25. Lexington, Kentucky: Univ. of Kentucky, 1978, p. 355-370.

DANIEL, G. Reginald. Machado de Assis: Multiracial Identity and the Brazilian Novelist. University Park: Pennsylvania State University Press, 2012.

DIXON, Paul. A lei da homeopatia: "Cantiga de esponsais". In: _ . Os contos de Machado de Assis: mais do que sonha a filosofia. Porto Alegre: Movimento, 1992, p. 4450.

FACIOLI, Valentim. Um defunto estrambótico: análise e interpretação das Memórias póstumas de Brás Cubas. São Paulo: Nankin, 2002.

FITZ, Earl. Machado de Assis. Boston: Twayne, 1989.

KINNEAR, J. C. Machado de Assis: To Believe or Not to Believe. Modern Language Review 71, p. 54-65, 1976.

LEJEUNE, Philippe. On Autobiography. Ed. Paul John Eakin. Trans. Katherine Leary. Minneapolis: University of Minnesota Press, 1989.

NUNES, Maria Luisa. The Craft of an Absolute Winner: Characterization and Narratology in the Novels of Machado de Assis. Westport, Connecticut: Greenwood, 1983.

SANTIAGO, Silviano. Retórica da verossimilhança. In: —. Uma literatura nos trópicos: ensaios sobre dependência cultural. São Paulo: Perspectiva, 1978, p. 29-48. TOSTA, Antônio Luciano. Machado de Assis: a obra entreaberta. Luso-Brazilian Review 41. Madison, Wisconsin, University of Wisconsin, p. 37-55, 2004.

PAUL DIXON is Professor of Portuguese and Spanish at Purdue University in West Lafayette, Indiana, where he has taught since receiving his $\mathrm{PhD}$ from the University of North Carolina in 1981. He is the author of O chocalho de Brás Cubas: uma leitura das Memórias póstumas (Edusp;Nankin, 2009), Os contos de Machado de Assis: mais do que sonha a filosofia (Movimento, 1992), Retired Dreams: Dom Casmurro, Myth and Modernity (West Lafayette: Purdue University Press, 1989) and Reversible Readings: Ambiguity in Four Modern Latin American Novels (University of Alabama Press, 1985),

Machado de Assis Linha, São Paulo, v. 8, n. 15, p. 134-149, junho 2015

Universidade de São Paulo - Faculdade de Filosofia, Letras e Ciências Humanas 
along with numerous articles. Besides teaching Brazilian and Spanish-American literature at Purdue, he has taught as a visiting professor at Universidade Federal do Rio Grande do Sul, Pontifícia Universidade Católica do Rio Grande do Sul and Universidade Feevale (Novo Hamburgo). E-mail: tudobem@purdue.edu.

Recebido: 13.03.2015

Aceito: 14.04 .2015

Machado de Assis Linha, São Paulo, v. 8, n. 15, p. 134-149, junho 2015

Universidade de São Paulo - Faculdade de Filosofia, Letras e Ciências Humanas 